\title{
E-Commerce Law, and WTO with Reference io Iran
}

\author{
BESHARAT Solmaz ${ }^{24}$
}

\begin{abstract}
World-wide, with the increasing proliferation of the Internet, E-commerce has become commonplace. E-commerce transactions take place between companies, companies and people or between different countries and consumers. E-commerce covers B2B (Business to Business), B2C (Business to Consumer), C2C (Consumer to Consumer), and G2C (Government to Consumer). E-commerce is widespread, but no standard law is uniformly followed by all consumers and countries. In the e-commerce space, WTO and UNCITRAL have attempted some standardization. Starting December 1996, UNCITRAL (United Nations Commission on International Trade Law) adopted the Model Law on Electronic Commerce, to protect consumers in different commercial activities. The WTO (World Trade Organization) goal is an open market scenario that reduces economic stressors, which could trigger armed conflict. WTO member countries are involved in more than $97 \%$ of world trade, including ecommerce, and every member state abides by its rules and regulations. For this reason, many non-members have applied for membership. Iran, which has applied more than twenty times for membership in WTO, thinks that WTO is important for its economy because as a negotiating table it encourages global economic development, cuts down protectionism like domestic market access barriers, and creates free trade conditions. How ready is Iran? This article briefly touches upon different aspects of e-commerce.
\end{abstract}

Keywords: E-commerce law, WTO, Iran, UNCITRAL, Cyberspace

JEL: K20

UDC: 004:339(55)

338.124.4

COBISS.SR-ID 265415948

\section{E-commerce origins}

In human history, e-commerce is a recent business process that cuts costs, increases speed of service and delivery, via the Internet, leading to savings for businesses and consumers. Ecommerce - globally commonplace - is transaction over the Internet involving buyers and sellers, goods and services, within or across national boundaries. It also included certain service offerings. E-commerce grew from EDI (Electronic Data Interchange). For more than four decades - the 1970s onwards - e-commerce grew from strength to strength to become a common e-market for consumers. Michael Aldrich - an English inventor cum entrepreneur was the first to hook up a TV to the supermarket to deliver groceries. In 1979, Aldrich joined a TV set to a transaction processing computer complete with accompanying phone line, and 'tele-shopping' - long distance shopping - was born. B2B (business to business) spread

${ }^{24}$ University of Mysore, India 
quickly, but B2C (business to consumer) had to wait for the World Wide Web, and home computers to become reality. Internet development is followed by e-commerce development - evolution in the former impacts the latter.

In the 1980s, e-commerce was around before the Internet took over, through credit cards, ATMs, and telephone banking. From the 90s, e-commerce virtual shops (e-shops or e-malls), e-procuring, e-auctioning (such as online auction sites like eBay), and virtual communities have gained new ground. The Internet (a.k.a. World Wide Web) opened up in 1994, and from 1995 to 1999, internet infrastructure like browsers helped in the growth of e-commerce.

In the past, transporting goods - in e-commerce - needed legal framework covering all transport documents, to help a receiver of goods with a 'guarantee of singularity', to guarantee security and avoid duplication.

In 2004, the Payment Card Industry (PCI) Security Standards Council was set up for businesses to work with enhanced security to protect consumers. PCI protects data from beginning to end, storage, different uses, etc. (Farnoud)

The most common forms of e-commerce cover B2B and B2C. B2B supplies goods and services between businesses, and uses e-infrastructure, like operating software, and e-markets, where buyers and sellers meet in virtual marketplaces.

B2C - e-commerce for consumers - covers goods and services, and info between consumers and sellers. E-retail and e-banking (personal finance operations) are part of B2C as are $\mathrm{C} 2 \mathrm{C}$ (consumer to consumer) transactions like e-auctions, etc.

G2C (government to citizen) is also catching up for various products that citizens need from their governments.

\section{History of WTO}

WTO (World Trade Organization) is a negotiating table that helps to administer GATT (General Agreement on Tariffs and Trade, 1994/1947). GATT was conceived after 1947 - post World War II - to help create open markets to cut down on economic stressors, which could trigger armed conflict that could lead to another world war. Cutting back unhelpful border restriction on trade, was the first step towards freer, and import open economies. WTO, which stands firm on market liberalization, followed GATT, and logically evolved to cover intellectual property rights, e-commerce, etc. thus extending the limited GATT regime.

When WTO was set up, one objective was to further commerce in a worldwide multilateral trading system. Other objectives include 'optimal use of the world's resources in accordance with the objective of sustainable development' and enhancing the trade prospects of developing countries. (Maciel)

The multilateral trading system, was founded on the tripod of non-discrimination, most favored nation (MFN), wherein countries cannot discriminate between trading partners, and national treatment, where imported goods should be treated at par with local goods once they enter the circulation of an economy. These three principles come into play when e-commerce impacts a nation's trading system. Other aspects impacted include a lack of agreement on customs duties - which only come into play when a product physically crosses a nation's borders.

These issues triggered the Work Program in Electronic Commerce in 1998, which empowered four councils of WTO to conduct inspections: The Council for Trade in Services (GATS), the Council for Trade in Goods (GATT), the Council for Trade-Related aspects of Intellectual Property Rights (TRIPS), and the Committee on Trade and Development (CTD).

The Work Program also states that the term 'Electronic Commerce' is understood to mean the production, distribution, marketing, sale or delivery of goods and services by electronic means.' (Maciel) 
From 1998 onwards, WTO has tackled the tricky area of e-commerce, after the Ministerial Declaration on Global Electronic Commerce. The same year, the OECD (Organization for Economic Cooperation and Development) put in place an Action Plan for Electronic Commerce - a supportive structure that offered directives for member states on the subject.

WTO has further support from UNCITRAL.

\section{UNCITRAL origins, e-commerce evolution and the Model Law}

In December 1966, the United Nations General Assembly created the United Nations Commission on International Trade Law (UNCITRAL). In 1988, UNCITRAL examined the need for laws for e-commerce contracts resulting in reports in 1991, where a 'standard communication agreement for use in international trade' was considered. In December 1996 after UNCITRAL adopted the Model Law on Electronic Commerce that protects consumers in different commercial activities - many nations adopted the Model Law. The Model Law helps countries with internationally accepted rules, removes legal obstacles, and creates a safe legal environment for e-commerce. The Model Law helps legislators of different countries where existing laws were either inadequate or non-existent - to cope with e-commerce and minimizes obstacles like paper documentation, 'signatures', etc. This makes the Model Law attractive to countries like Iran. But the Model Law does not completely address malfunctions of the information system, like system errors, or failure to deliver a message. (UNCITRAL)

The reason UNCITRAL legislations are of such importance is that the establishment of legal standards for data messages/e-commerce is absolutely essential for internet trading, and should be continually updated as internet technology evolves. The legal validity of a contract will change just as internet evolution changes the way e-commerce is done. Data messages have legal acceptance and validity in e-commerce transactions. UNCITRAL however, is not binding to any participant in an e-commerce contract.

The Working Group on International Payments can identify possible statutory provisions, to establish uniform legal rules on e-commerce, focus on contracts, risk, liability of partners and a legally secure environment.

\section{E-commerce law}

The Internet has transformed exponentially business dealings with goods and services being exchanged electronically. E-commerce has some of the fastest growing business models in the world today. Side by side, there is a growth spurt of e-commerce law, covering not only e-commerce but also cyber crime, intellectual property rights, privacy issues, jurisdiction and choice of law. E-commerce covers EDIC (Electronic Data Interchange), electronic payment systems, inventory, info and product support, service and delivery, order management, e-mail, bar codes, smart cards, etc. Tough cyber laws are necessary to authenticate both the producer and customers identities, and ensure no hacking or other forms of attack ruin the authenticity of electronically transmitted documents. In general, weaknesses of existing laws on legal issues, customs and taxes, plus the lack of adequate written laws dealing with electronic crime, are serious obstacles.

\section{E-commerce and WTO}

From 1998, WTO members have tried to deal with pressing issues like:

What classifies an electronically delivery as a goods of service?

When does an e-commerce service become across the border or within a country?

How much does WTO cover e-commerce transactions? 


\section{WTO and e-commerce policy areas}

Currently, two policy areas cover the broad territory of e-commerce. The first includes organizations with direct involvement with e-commerce, like the UNCTD (United Nations Conference on Trade and Development) and OECD, which covers a large paradigm of ecommerce activity like the OECD Ministerial Meeting in the Digital Economy: Innovation, Growth and Social Prosperity, etc.

The second area covers other challenges that may impact e-commerce such as: the WIPO (World Intellectual Property Organization), which covers intellectual property, the ITU (International Telecommunication Union), which deals with infrastructure, and IOS (the International Organization for Standardization), which enables uniform standardization. The UN Human Rights Council covers the very important aspect of privacy, which enables data to move freely, without which e-commerce ceases to work effectively.

In theory, all the above should enable all parts of e-commerce, but the only pillar working effectively is services. The EU and seven other countries covered trade features of e-commerce that would fall under the WTO umbrella, in four different parts: regulatory frameworks, open markets, enabling easier e-commerce processes and a multilateral trading system. According to WTO regulations, products bought and paid for over the Internet but delivered physically are subject to WTO rules. (Maciel)

\section{E-commerce advantages and disadvantages}

E-commerce has many advantages. With minimum investment, producers can connect with suppliers or businesses worldwide, lower the costs of business processes, communicate speedily, and use online sales as a complement to traditional business models by opening new market segments. Buyer advantages include time saved, having access to better variety of goods, avoiding traffic jams, and speedy deliveries, as well as access to e-auctions.

But e-commerce comes with disadvantages like security issues for online payments, insufficient internet access, people's preference to pay by cash and no uniform code for legal issues, and hacking. This is why robust e-commerce laws are important. (Mirescu)

\section{Iran and WTO}

WTO member countries cover more than $97 \%$ of world trade. Iran applied for WTO membership in July 1996 and from then to May 2001, Iran's application was not accepted since the US objected. From 2001 to 2005, Iran's application for WTO membership came up 22 times. In May 2005 - the twenty second time - Iran's application for membership was finally accepted by the members. It now has observer status. (WIKIPEDIA)

In 2017, WTO had 164 members. It carries major economic clout. Its member countries are involved in more than $97 \%$ of world trade, and every member state abides by its rules and regulations. Countries that are not yet WTO members face isolation of their economies.

Membership of WTO comes with the power of a veto, and Iran's application was vetoed twenty-one times by the US. (Doagoo and Saeidi)

\section{Possible gains for Iran from WTO}

The biggest economy in the world - the US - backs trade liberalization reforms as the key to market freedom that can lead to progressive political liberalization. This is specifically applicable to Iran. WTO full membership can be the trigger for the complete liberalization of Iran's economy. The reason - WTO reforms could set off a chain reaction that would enable 
Iran to integrate its economy with the global trading system - minimizing MFN (most favored nation) status, national treatment obligations of GATT Articles I and III, including minimizing of tariff and non-tariff barriers. This should lead to privatization of state owned, and, state trading, enterprises (SOE and STE), bring in much needed FDI (Foreign Direct Investment), and adherence to intellectual property rights - including patents, copyrights, trademarks, etc. as implied in TRIPs (Agreement on Trade-Related Aspects of Intellectual Property Rights). (Aslan \& Bhala)

Iran's joining the WTO comes with many benefits. A few include foreign investment and economic diversity with export of non-oil revenue products, and healthy competition that would dissolve unnecessary subsidies. Above all cheap energy in Iran could give it advantages in the non-oil sector, technological breakthroughs would give employment to a young workforce, and better access to the global economy.

\section{Issues for Iran's membership of WTO}

WTO membership is believed to be a panacea for many of Iran's ills, like the unemployment rate, inflation, pollution, etc. and lead to upheavals, which would trigger an economic upturn that makes Iran's economy more competitive. If Iran becomes a full-fledged member of the WTO, the following issues could crop up.

The Iranian government could withdraw from some areas in Iran's economy like lossmaking industries (which WTO membership would make necessary).

Healthy competition would dissolve unnecessary subsidies. When Iran opens its economic borders, foreign investors, new technology and job opportunities would enter Iran. Foreign investment means infusion of foreign capital. Iran's economy would need to change.

Iran must step up its $R \& D$ for new technology. And it needs to improve its banking, taxation, and insurance, and control corruption. The government should make transparency the norm, remove complex legalities.

Another issue would be the balance of payments. If a large number of goods are imported, how will the payments be made? Would they cut into Iran's foreign exchange reserves? If oil revenue is used, could diversification away from an oil-based economy come to a standstill?

Exports may be hit by restrictions from other countries. For qualitative exports, has Iran have enough infrastructure? Growth in Iran is mostly oil driven, which is why diversification like e-commerce with attendant laws is important.

A few important issues must be tackled before WTO can truly impact Iran's economy.

First, Islamic perspective towards economic productivity should be baseline for WTO considerations to be met. The Iranian Civil Code of 1936 does not protect consumers in ecommerce transactions. B2C contracts should be rooted in societal and economic conditions to protect consumers. The 1936 Iranian Civil Code contains mainly Islamic law principles.

Islam has an important principle that is part of the Civil Code: La Zarar, which covers and protects consumers on the receiving end of broken, missing, inaccurate goods or services in a contract, which can, because of breach of contract, be eligible for compensation for the same. In a contract, the freedom to choose, and principle of fault are both covered.

However, the Civil Code does not specifically cover B2C contracts.

In Article 190, to protect the freedom of contract, the following conditions are needed:

- Mutual consent from both parties.

- A definite service or item should be the base for the contract

- Conditions in the contract should adhere to the law

Second, lack of proper implementation of laws and international standards by relevant agencies means there is a lack of public awareness of issues relating to information technology. 
Third, lack of proper protection for consumer rights, wherein criminal laws involving fraud, forgery, violation of messages supporting data, consumer rights, breach of copyright, trade secrets, intellectual property rights, trade secrets, and trademark infringement need to be taken care of.

Fourth, a lack of banking laws and regulations can result in unacceptable documentation, and electronic signatures, both of which are necessary for proper implementation of ecommerce.

Fifth, Iran also lacks infrastructure, and economic, legal, cultural, social and political framework for the steady development of e-commerce. WTO, IMF, World Bank - these can help Iran transition to a modern day, liberal economy. (Doagoo and Saiedi).

\section{Iran's readiness for WTO post 2000}

Iran wants WTO membership, but still needs to think out clearly the effects of economic security on the one hand, and protection of Iran's national priorities on the other.

In Iran, internet transaction legalities fall under the E-commerce Law of 2004, and the Consumer Rights Protection Act of 2009.

Before full membership of WTO, Iran must re-jig areas like the constitution, labor law, trade FDI, insurance, banking, taxation, customs law, for WTO to be implemented successfully.

A WTO challenge is helping both foreign and local businesses to have some kind of order within a WTO member country. WTO encourages lifestyle and QOL (quality of life) improvement through exchange of goods and services that enhance economic development, democracy, and removal of destabilizing factors in economic growth.

Iran's joining the WTO comes with benefits and challenges. WTO membership is believed to be a panacea for many of Iran's ills, like the unemployment rate, inflation, pollution, etc. and possibly lead to upheavals, which would trigger an economic upturn that makes Iran's economy more competitive.

Foreign investment and economic diversity, with export of non-oil revenue products, healthy competition to dissolve unnecessary subsidies, technological breakthroughs that would open the job market to a young workforce and cheap energy in Iran would make Iran a champion in the non-oil sector and in the global economy. When Iran opens its economic borders, foreign investors, new technology and job opportunities would enter Iran.

\section{E-commerce laws and consumer protection in Iran in 2017}

Law is grounded in the real world. Outdated contract law - in any country - should be expanded to protect consumers in e-commerce. As the use of Internet technologies continues to evolve, and involve the latest technologies, law must keep pace to provide consumers security. Iranian law should evolve step by step to keep up with ever changing technological landscape, and this must be done on a yearly basis.

In 2017, to protect consumers, Iran juggles old laws (from 1930s), and new e-commerce law (of the 2000s) like the Electronic Commerce Law (ECL) in 2004, the Consumer Rights Protection Act (CRPA) in 2009, and the Computer Crimes Act and Penal Code.

World-wide, there is no consensus on laws that protect consumer rights.

Consumer protection laws need to cover every aspect of a commercial transaction including e-commerce transaction - and especially so if transaction is carried out from one country to another. B2C transactions necessitate investment in consumer protection and rights through law. 
Besides, lack of an appropriate legal framework in the area of information and infrastructure security and cyber crime, is commonplace in developing countries, and this prevents the complete enjoyment of e-commerce. (Bagheri \& Hassan)

\section{Cyberspace}

Internet, intranet, and the World Wide Web all combined are called cyberspace, and any legal issue is covered by cyber laws. E-commerce is an internet-enabled business methodology less than a century old. E-commerce works almost instantly, such is the speed of doing business on the Internet. E-commerce processes info instantly, therefore bottlenecks like transportation distances, customs regulations, language barriers, are easily overcome. Ecommerce may resemble traditional paper-based commercial contracts, with buyers, sellers, goods and services, but still faces legal challenges. An e-commerce transaction is basically an electronic contract. Technology might outpace law, but e-commerce remains commerce that copies traditional commerce - buying, selling, goods, services, deliveries, and payments, with however less people and paper interactions than traditional commerce.

Legal challenges include methodology to replicate traditional signed paper documents, and how nations worldwide must enforce paper-based modalities to e-commerce such as signatures, time and date stamps, for proof of dispatch and delivery, plus witnesses, notaries to verify transactions, etc. These also include rules of evidence and connected laws remain relevant for computer-based transactions.

It is obvious that the law that exists where the original transaction took place is valid for ecommerce contracts and is the choice of law. In contract disputes, the choice of law of that jurisdiction, rules that the place of contract is the valid place for the law to be enacted.

An agreement between parties is held to be legally valid if the parties want to create a contract, and, agreed to an offer with specific terms, acceptance of the offer and mutually agreed payment after delivery is made. In a valid contract, all parties should consent equally, and terms should be clear, for payment and delivery. Breach of contract occurs when one party fails in satisfactory performance, and the hurt party is then liable for compensation. Consumer rights should be enforced strictly in e-commerce. A few helping aids to focus consumer attention on important points should be visual, like bold or capital letters, etc.

Intellectual property rights should also be protected like copyrights, trademarks, patents, internet domain names, etc. Contractual parties should be alert about computer crimes.

Many authorities and nations have implemented digital signature legislation.

UNCID (Uniform Rules of Conduct for Interchange of Trade Data by Tele-transmission) 1988, is the brain child of the ICC (International Chamber of Commerce) with focus on security features like verification of a sender's identity, the receipt, content, confidential security and storage of data. Agreements provide surety in e-commerce.

The important issue of payment is covered by credit cards, and EFT (Electronic Fund Transfer) agreements between a financial institution and its customer, and credit and debit based electronic payments. Security issues in domestic and international e-commerce agreements are still evolving and not yet foolproof. Companies like Amazon - who have patented a business model - can sue other companies for copying their e-business model.

Due to the Internet, and e-commerce, the law of different nations is not completely clear whether computer crimes come under technology specific laws or be tried under general traditional criminal law. (Bakshi \& Suri)

\section{WTO and e-commerce issues}

WTO covers e-commerce security and privacy, TRIPS, Trademarks, domain names, etc. 
Market access issues covering electronically transmitted products, and customs treatment of the same are covered by WTO. Infrastructure requirements for e-commerce include trade in information technology and telecommunication services. Government purchases through electronic commerce can transform traditional forms of trade and commerce. An important question is: How does WTO facilitate ease in trade and customs through EDI? (Mujahid)

\section{Conclusions}

The reality of 2017 is that a message can reach any part of the globe in next to no time and delivery of goods can take place at the receiver's convenience.

In Iran today, e-commerce, internet sites, tele home shopping networks, add different dimensions to the way Iranians can now shop. Iran's lawmakers need to incorporate ecommerce legislation from developed countries like the US and France, to completely and adequately protect consumers in $\mathrm{B} 2 \mathrm{C}$ transactions on the Net. It needs separate laws to govern B2C e-commerce as internet technologies continue to evolve at breakneck speed. The allimportant aim of blanket consumer protection should be the focus of Iran's current law regimen. Laws should be precise. Iran should strive to balance both Islamic perspective (La Zarar) and internet consumer contract protection, and overhaul its law regime. For this it must upgrade its technology infrastructure, to protect consumer rights specifically in e-commerce and build up a consumer centric legal environment. (Bagheri \& Hassan)

\section{REFERENCES}

1. A.B. Doagoo, M. Saeidi (2014). Iran's accession to the WTO, the basis for sustainable economic development. Sc. Jour. of Rev. at 304-312.

2. Author Miva, The History of Ecommerce: How did it all begin? (2011). https://www.miva.com/blog/the-history-of-ecommerce-how-did-it-all-begin/

3. Hadi Farnoud, why eCommerce is the next big thing in Iran, (2014). https://www.linkedin.com/pulse/why-ecommerce-next-big-thing-iran-hadi-farnoud

4. https://en.wikipedia.org/wiki/Iran_and_the_World_Trade_Organization

5. Iran and the World Trade Organization - Wikipedia.

6. Maciel, M. (2016): E-commerce in the WTO: the next arena of Internet Policy Discussions? (2016) https://www.diplomacy.edu/blog/e-commerce-wto-next-arenainternet-policy-discussions.

7. Bakshi, P.M., Suri, R.K. (2002). Bharat's Handbook of Cyber and E-Commerce Laws, at 196-254 ( $1^{\text {st }}$ ed. 2002).

8. Parviz, B., Hassan., K.H. (2012). E-Commerce and Consumer Protection in Iran: A Legal Framework. 2012, available at https://www.medwelljournals.com/abstract/?doi=ibm.2012.333.339

9. Reza, A., Raj, B. (2010). Iran and the WTO, For. Pol. at 1.

10. Silviu V. M. (2010)., The Premises and the Evolution of Electronic Commerce: Jour. of Know. Managemt, Eco. and Info. Tech. www.scientificpapers.org

11. UNCITRAL, United Nations Commission on International Trade Law Model Law on Electronic Commerce with Guide to Enactment (1996).

12. Yousaf, H. M. (2004). E-Commerce and WTO - Digitalizing Trade Liberalization, (2004).

\section{Article history:}

Received 7 March 2018

Accepted 10 June 2018 